\title{
Tingginya Infeksi Chlamydia trachomatis pada Kerusakan Tuba Fallopi Wanita Infertil
}

\author{
Wafirotus Sariroh, Relly Yanuari Primariawan \\ Departemen Obstetri dan Ginekologi, Fakultas Kedokteran Universitas Airlangga, \\ RSUD dr. Soetomo, Surabaya
}

\begin{abstract}
ABSTRAK
Tujuan: Untuk mengetahui gambaran infeksi C. trachomatis pada kerusakan tuba fallopi wanita infertil.

Bahan dan Metode: Penelitian ini melibatkan 42 wanita yang menjalani laparoskopi dalam tata laksana infertilitasnya. Infeksi $C$. trachomatis diperiksa menggunakan metode PCR dari usapan endoserviks dan $\operatorname{IgG} C$. trachomatis diperiksa menggunakan metode ELISA dari darah vena. Kondisi tuba fallopi dilakukan evaluasi saat laparoskopi.

Hasil: Didapatkan C. trachomatis sebesar 14,29\% dari PCR usapan endoserviks dan 38,10\% dari IgG C. trachomatisdi darah. Sebagian besar tuba fallopi pada subyek dengan infeksi $C$. trachomatis menunjukkan kerusakan, ditandai adanya adhesi perituba, oklusi tuba, fimosis fimbria atau hidrosalping saat laparoskopi. IgG $C$. trachomatis berbeda signifikan pada kerusakan tuba fallopi $(\mathrm{p}=0.01)$, sedangkan endometriosis dan riwayat operasi sebagai faktor risiko tidak didapatkan perbedaan yang signifikan $(\mathrm{p}=0.26$ dan $\mathrm{p}=0.27)$. Subyek dengan $\mathrm{IgG} C$. trachomatis memiliki OR: 5. 5 (95\% CI 1. 42-21. 7)untuk terjadi kerusakan tuba fallopi. IgG C. trachomatis memiliki sensitifitas $62,5 \%$, spesifisitas $81,25 \%$, PPV $62,5 \%$ dan NPV $81,25 \%$ dalam mendeteksi kerusakan tuba fallopi bila dikonfirmasi dengan hasil laparoskopi.

Simpulan: Angka kejadian infeksi $C$. trachomatis pada wanita infertil cukup tinggi. Pemeriksaan IgG $C$. trachomatis dapat menjadi penanda adanya kerusakan tuba fallopi.
\end{abstract}

Kata Kunci: C. trachomatis, infertilitas, kerusakan tuba fallopi, IgG, PCR

\begin{abstract}
Objectives: To know the description of C. trachomatis infection in tubal dysfunction of infertile women

Materials and Methods: This study involves 42 women who underwent laparoscopy procedure in their infertility work up. Chlamydia trachomatis was detected using PCR from endocervical swabs and IgG was detected using ELISA from blood. Evaluation of the fallopian tube was done during laparoscopy procedure.

Results: C. trachomatis was detected in $14,29 \%$ by PCR of endocervical swab and IgGin serum was detected in $38,10 \%$. Most of the infected women in this study have fallopian tube dysfunction, confirmed by laparoscopic visualization of peritubal adhesion, tubal occlusion, fimbriae phimosis, or hydrosalphing. IgG $C$. trachomatis is significantly different between normal and dysfunctional fallopian tube $(\mathrm{p}=0.01)$. The occurrence of endometriosis and previous surgery was not statistically different $(\mathrm{p}=0.26$ and $\mathrm{p}=0.27)$. Women with $\mathrm{IgG} C$. trachomatis had OR: 5.5 to get fallopian tube dysfunction(95\% CI, 1. 42-21. 7). IgG C. trachomatis has sensitivity of $62.5 \%$ and specificity of 81 . $25 \%$, PPV of $62,5 \%$ and NPV of $81,25 \%$ in detecting dysfunctional tube compared to laparoscopy.

Conclusion: The incidence of $C$. trachomatis infection is quite high in infertile women. IgG Chlamydia trachomatis can be used as a marker of fallopian tube dysfunction.
\end{abstract}

Keywords: Chlamydia trachomatis, infertility, fallopian tube dysfunction, IgG, PCR

Correspondence: Wafi Sariroh, Departemen Obstetri dan Ginekologi, Fakultas Kedokteran Universitas Airlangga,

RSUD Dr. Soetomo, Surabaya, Jawa Timur, Indonesia, phone:+62315501474, email: iwafir18@yahoo.com

\section{PENDAHULUAN}

Infertilitas dialami sekitar 80 juta pasangan usia reproduksi. Infertilitas dikarenakan faktor tuba fallopi menyebabkan $40 \%$ dari infertilitas tersebut. Kerusakan tuba fallopi yang mempengaruhi infertilitas antara lain adanya perlekatan, oklusi, dan hidrosalping. Infeksi Chlamydia trachomatis berhubungan dengan peningkatan risiko kerusakan tuba fallopi. ${ }^{1}$ Adanya heat shock protein 60 (hsp) Chlamydia, reaksi imun tipe lambat serta pelepasan sitokin merupakan mekanisme yang menimbulkan kerusakan pada tuba fallopi. ${ }^{2,3}$ Prevalensi infeksi C. trachomatis pada wanita Eropa berkisar 1,7$17 \% .^{4}$ Pada wanita infertil, prevalensi infeksi ini lebih tinggi. Di Tehran didapatkan 12,4\% infeksi dengan menggunakan pemeriksaan PCR dari usapan endoserviks wanita infertil. ${ }^{5}$ Di Nigeria, prevalensi $\operatorname{IgG} C$. trachomatis pada wanita infertil mencapai $74 \% .^{6}$
Di Indonesia angka kejadian infeksi Chlamydia trachomatis secara global belum diketahui. Penelitian sebelumnya dilakukan terhadap populasi yang dianggap berisiko. Pada populasi pekerja seks komersial wanita di Indonesia didapatkan prevalensi infeksi Chlamydia trachomatis mencapai 35-55\%. ${ }^{7}$ Di Surabaya prevalensi infeksi Chlamydia trachomatis pada remaja wanita sebesar $2,1 \%^{8}$ dan pada remaja pria sebesar $2,3 \%$. ${ }^{9}$ Pada wanita dengan servisitis di RSUD Dr. Soetomo Surabaya sebesar 52,6\%, ${ }^{10}$ sedangkan di RSCM Jakarta sebesar $12,66 \%$. Tidak didapatkan data prevalensi infeksi Chlamydia trachomatis pada pasien yang mengalami infertilitas di Indonesia karena pemeriksaan Chlamydia trachomatis belum secara rutin dikerjakan pada infertilitas. 
Penelitian mengenai infeksi Chlamydia trachomatis pada wanita infertil belum pernah dilakukan di Surabaya. Karena infeksi Chlamydia trachomatis di bidang infertilitas merupakan salah satu faktor risiko kerusakan tuba fallopi, maka peneliti ingin melakukan penelitian terhadap wanita infertil yang menjalani laparoskopi. Hal ini dimaksudkan agar didapatkan juga data mengenai kondisi tuba fallopi dari wanita tersebut.

\section{BAHAN DAN METODE}

Penelitian ini dilakukan di klinik fertilitas Graha Amerta dan Gedung Bedah Pusat Terpadu RSUD dr. Soetomo Surabaya yang dilakukan tindakan laparoskopi mulai Desember 2014 hingga Maret 2015 secara cross sectional. Penderita yang menjalani operasi laparoskopi, diberikan penjelasan dan menandatangani informed consent untuk berpartisipasi dalam penelitian ini. Penelitian ini mendapat kelayakan etik dari Komisi Etik Fakultas Kedokteran Universitas Airlangga/RSUD dr. Soetomo Surabaya. Sampel penelitian ini adalah wanita infertil baik infertilitas primer maupun sekunder dengan rentang usia 20-40 tahun, yang menjalani laparoskopi dalam penatalaksanaan infertilitas. Kriteria inklusi adalah wanita infertil yang menjalani laparoskopi, sedangkan kriteria eksklusi adalah pasien yang menolak mengikuti penelitian. Usapan endoserviks dilakukan dengan menggunakan swab steril setelah membersihkan serviks dari lendir. Swab steril kemudian dimasukkan ke dalam tabung berisi Phosphate Buffer Solution2-3cc, untuk dilakukan pemeriksaan PCR Chlamydia trachomatis dengan amplifikasi DNA. Selain itu, dilakukan juga pengambil-an darah vena sebanyak 3$5 \mathrm{cc}$ untuk dilakukan pemeriksaan antibodi terhadap IgG Chlamydia trachomatis dengan menggunakan metode Enzym Linked Immunoassay (ELISA). Interpretasi hasil pe-meriksaan IgG adalah sebagai berikut: kadarantibodi $\mathrm{IgG}<2020 \mathrm{IU} / \mathrm{ml}=$ negatif; kadar 20-25 IU $/ \mathrm{ml}=$ indeterminate; kadar $>25 \mathrm{IU} / \mathrm{ml}=$ positif. Kondisi tuba fallopi dilakukan evaluasi saat operasi laparoskopi.

\section{HASIL DAN PEMBAHASAN}

Penderita yang memenuhi kriteria inklusi dan eksklusi sebanyak 42 dengan rerata usia 32.8 tahun dengan rentang 25 hingga 40 tahun. Rerata lama infertilitas adalah 5,58 tahun dengan rentang 2 hingga 13 tahun. Pemeriksaan PCR terhadap usapan endoserviks mendeteksi Chlamydia trachomatis pada 14,29\% sampel. Rerata usia kelompok ini $(33,17 \pm 3,4)$ tahun dan rerata lama infertil $(6,17 \pm 3,08)$ tahun. IgG Chlamydia trachomatisdidapatkan pada $38,10 \%$ sampel. Rata-rata usia pada kelompok yang didapatkan IgG Chlamydia trachomatis maupun tidak, didapatkan hasil yang serupa yaitu $(32,13 \pm 4,75)$ tahun dan $(32,46 \pm 3,92)$ tahun. Lama infertilitas didapatkan lebih besar yaitu $(5,41 \pm 2,93)$ tahun pada kelompok dengan IgG daripada kelompok tanpa IgG yaitu $(4,98 \pm 3,07)$ tahun.

Tabel 1. Karakteristik sampel penelitian

\begin{tabular}{|c|c|c|}
\hline Karakteristik & Frekuensi & Persentase \\
\hline \multicolumn{3}{|l|}{ Usia } \\
\hline 25-30 tahun & 9 & $21,42 \%$ \\
\hline 30-35 tahun & 25 & $59,52 \%$ \\
\hline$>35$ tahun & 8 & $19,04 \%$ \\
\hline \multicolumn{3}{|l|}{ Lama infertilitas } \\
\hline $1-3$ tahun & 15 & $35,71 \%$ \\
\hline$>3-5$ tahun & 12 & $28,57 \%$ \\
\hline$>5$ tahun & 15 & $35,71 \%$ \\
\hline \multicolumn{3}{|l|}{ Keluhan penyerta } \\
\hline Dismenorea & 9 & $21,42 \%$ \\
\hline Nyeri panggul & 1 & $2,38 \%$ \\
\hline Keputihan & 5 & $11,90 \%$ \\
\hline Perdarahan & 2 & $4,76 \%$ \\
\hline $\begin{array}{l}\text { Dismenorea + nyeri panggul + } \\
\text { dispareuni }\end{array}$ & 4 & $9,52 \%$ \\
\hline $\begin{array}{l}\text { Dismenorea + nyeri panggul + } \\
\text { keputihan }\end{array}$ & 1 & $2,38 \%$ \\
\hline Dismenorea +keputihan & 1 & $2,38 \%$ \\
\hline Tidak ada keluhan & 17 & $40,47 \%$ \\
\hline \multicolumn{3}{|l|}{ Temuan laparoskopi* } \\
\hline Perlekatan perituba & 9 & $21,42 \%$ \\
\hline Fimosis fimbria & 6 & $14,28 \%$ \\
\hline Oklusi tuba & 15 & $35,71 \%$ \\
\hline Hidrosalping & 2 & $4,76 \%$ \\
\hline Endometriosis & 23 & $54,76 \%$ \\
\hline Mioma uteri & 9 & $21,42 \%$ \\
\hline Tanda Fitz-Hugh-Curtis & 3 & $7,14 \%$ \\
\hline Normal pelvis & 5 & $11,90 \%$ \\
\hline
\end{tabular}

Berdasarkan kadar antibodi IgG Chlamydia trachomatis, kelompok dengan kerusakan tuba fallopi memiliki kadar yang lebih tinggi dibandingkan kelompok dengan tuba fallopi normal (Gambar 1). Kadar antibodi terhadap IgG Chlamydia trachomatis pada tuba fallopi rusak memiliki median sebesar 92,95 IU/ml (nilai minimal: 2,10 dan maksimal: 260,0 IU/ml), sedangkan pada tuba fallopi normal memiliki median sebesar 6,25 IU/ml (nilai minimal: 2,30 dan maksimal: 41,60 IU/ml). Berdasarkan uji chi square didapatkan infeksi Chlamydia trachomatis merupakan faktor resiko yang berbeda signifikan, sedangkan endomteriosis dan riwayat operasi didapatkan nilai yang tidak signifikan. IgG Chlamydia trachomatis memiliki OR 5. 5 (CI=95\%, 1. 42-21. 7). Pemeriksaan IgG Chlamydia trachomatis memiliki sensitivitas $62,5 \%$ dan spesifisitas $81,25 \%$ dalam mendeteksi kerusakan tuba fallopi dengan menggunakan laparoskopi sebagai pemeriksaan standar dalam mengevaluasi kondisi tuba fallopi. Nilai PPV pemeriksaan ini adalah 62,5\% dan NPV 81,25\%. Kondisi tuba fallopi pada sampel penelitian beserta faktor risiko kerusakan tuba meliputi infeksi Chlamydia trachomatis, endometriosis dan riwayat operasi sebelumnya tampak pada Tabel 2 . 


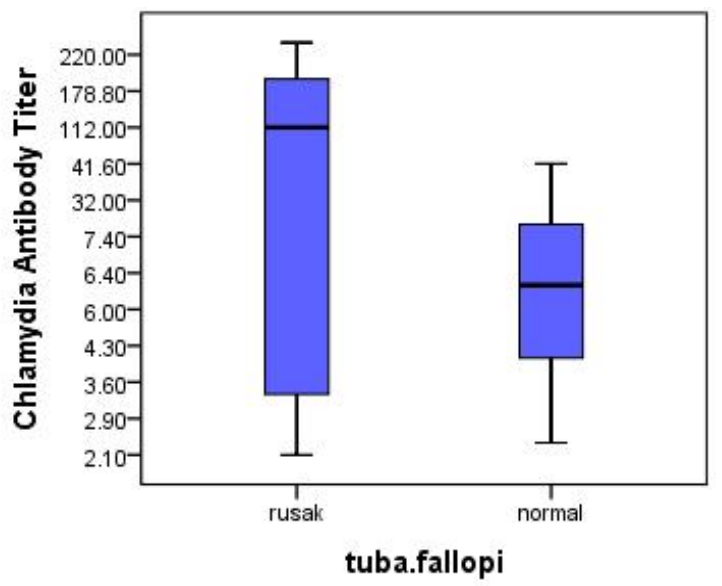

Gambar 1. Sebaran data kadar antibodi terhadap imunoglobulin G Chlamydia trachomatis berdasarkan kondisi tuba fallopi.

Tabel 2. Kondisi tuba fallopi berdasar laparoskopi dan faktor risiko

\begin{tabular}{|c|c|c|c|}
\hline & Tuba fallopi normal & Tuba fallopi rusak & Total \\
\hline Rata-rata usia (tahun) & $32,04 \pm 3,98$ & $32,81 \pm 4,62$ & $32,33 \pm 4,2$ \\
\hline Rata-rata lama infertil (tahun) & $4,21 \pm 2,22$ & $6,65 \pm 3,49$ & $5,14 \pm 2,98$ \\
\hline Total & $26(61,91 \%)$ & $16(38,09 \%)$ & $42(100 \%)$ \\
\hline \multicolumn{4}{|l|}{ Chlamydia trachomatis } \\
\hline - $\quad \operatorname{Ig} \mathrm{G}(+)$ & $6(37,50 \%)$ & $10(62,50 \%)$ & $16(100 \%)$ \\
\hline - $\quad \operatorname{Ig} \mathrm{G}(-)$ & $20(76,92 \%)$ & $6(23,08 \%)$ & $26(100 \%)$ \\
\hline \multicolumn{4}{|l|}{ Endometriosis } \\
\hline - $\quad$ Endometriosis (+) & $16(69,57 \%)$ & $7(30,43 \%)$ & $23(100 \%)$ \\
\hline - $\quad$ Endometriosis (-) & $10(52,63 \%)$ & $9(47,37 \%)$ & $19(100 \%)$ \\
\hline \multicolumn{4}{|l|}{ Riwayat operasi } \\
\hline - $\quad$ Riwayat operasi (+) & $3(100 \%)$ & $0(0 \%)$ & $3(100 \%)$ \\
\hline - $\quad$ Riwayat operasi (-) & $23(58,97 \%)$ & $16(41,03 \%)$ & $39(100 \%)$ \\
\hline
\end{tabular}

$\mathrm{P}<0,05$ : tidak signifikan

\section{Karakteristik subyek penelitian}

Rata-rata usia sampel penelitian ini 32,8 tahun. Penelitian di Tokyo yang menilai hubungan infeksi Chlamydia trachomatis dan kerusakan tuba fallopi juga mendapatkan rata-rata usia 32,2 tahun. ${ }^{11}$ Hal ini berhubungan dengan penuruan fekunditas wanita mulai usia 32 tahun dan makin menurun bermakna setelah 35 tahun. Hal ini menyebabkan tatalaksana infertilitas yang lengkap termasuk tindakan laparoskopi dikerjakan pada kelompok usia tersebut.

Lama infertilitas pada penelitian ini rata-rata adalah 5,58 tahun dengan rentang antara 2 sampai 13 tahun. Didapatkan jumlah yang hampir sama banyak antara lama infertilitas 1-3 tahun, >3-5 tahun, dan >5 tahun yaitu masing-masing sebanyak 15 (35,71\%), 12 $(28,57 \%)$, dan $15(35,71 \%)$. Hasil ini berbeda dari penelitian yang dilakukan Hiroi dkk dimana rata-rata lama infertilitas adalah 3,8 tahun. Penelitian lain di Amerika Serikat didapatkan rata-rata lama infertilitas adalah 3,58 tahun. Banyak wanita infertil di Indonesia yang tidak mencari penegakan diagnosis lebih dini karena pengobatan infertilitas dan tindakan laparoskopi masih dinilai mahal, sehingga rata-rata lama infertilitas subyek penelitian ini menjadi lama dibandingkan dengan studi lain terutama di negara maju.

Dari hasil laparoskopi yang dilakukan pada beberapa subyek ditemukan lebih dari 1 temuan kerusakan tuba dengan total didapatkan 37 subyek yang didapatkan kelainan. Hanya 5 subyek $(11,90 \%)$ yang dari hasil laparoskopi didapatkan kondisi normal pelvis. Untuk tuba fallopi yang mengalami kerusakan total didapatkan pada 16 subyek $(38,10 \%)$.

\section{Pemeriksaan isolat Chlamydia trachomatis}

Pada penelitian ini, prevalensi infeksi Chlamydia trachomatis pada wanita infertil yang menjalani laporoskopi adalah sebesar 14,29\% berdasar pemeriksaan PCR. Teknik PCR dengan amplifikasi DNA merupa- 
kan pemeriksaan yang direkomendasikan oleh WHO dan CDC untuk mendeteksi adanya infeksi aktif bakteri ini. Prevalensi di Tehran didapatkan 12,4\%12 sedangkan di Indiasebesar 13,5\% pada wanita infertil dengan metode yang sama. ${ }^{13}$ Pada sebuah meta-analisis menyimpulkan prevalensi infeksi Chlamydia trachomatis di populasi umum wanita sebesar $1,1 \%-10,6 \% .^{14}$ Hal ini menunjukkan bahwa kejadian infeksi Chlamydia trachomatis lebih banyak terjadi pada populasi wanita dengan infertilitas dibandingkan populasi umum.

Deteksi infeksi Chlamydia trachomatis pada populasi umum ditujukan untuk menemukan dan menangani infeksi dengan tujuan mencegah terjadinya komplikasi yang merugikan di kemudian hari, seperti infertilitas, nyeri kronik, kehamilan ektopik, persalinan prematur, ataupun penularan infeksi dari ibu ke bayi saat proses persalinan. Bila tidak tertangani, 20\% dari penyakit radang panggul simtomatik akan menjadi infertil; $18 \%$ akan mengalami nyeri panggul kronis; dan 9\% akan mengalami kehamilan ektopik di tuba fallopi. ${ }^{15}$ Adapun deteksi infeksi Chlamydia trachomatis pada wanita dengan infertilitas memiliki pertimbangan yang berbeda. Penelitian infeksi Chlamydia trachomatis pada wanita yang menjalani IVF didapatkan bahwa respon imun di serviks terhadap heat shock protein $60-\mathrm{kDa}$ Chlamydia (Chsp60) berhubungan dengan luaran IVF yang buruk. Hal ini dimungkinkan karena proses autoimun terhadap hsp $60-\mathrm{kDa}$ manusia yang homolog. ${ }^{16}$

Penelitian dengan hasil serupa menyimpulkan bahwa adanya infeksi atau reaktivasi respon imun terhadap heat shock protein Chlamydia trachomatis dapat menginduksi reaksi inflamasi di uterus yang mengganggu proses implantasi embrio dan atau memfasilitasi reaksi penolakan di uterus setelah embrio transfer pada IVF. ${ }^{17}$ Meta-analisis juga menyimpulkan bahwa hidrosalping yang merupakan bentuk kerusakan tuba fallopi akibat infeksi ini menyebabkan efek yang merugikan pada wanita infertil yang menjalani IVF. Efek tersebut berupa penurunan angka keberhasilan kehamilan, keberhasilan implantasi, kelahiran hidup, dan peningkatan kejadian abortus. ${ }^{18}$ Bila infeksi aktif bakteri ini tidak terdeteksi dan tertangani, maka akan menimbulkan efek yang kurang baik terhadap luaran dari proses penanganan infertilitasnya, khususnya dalam proses IVF.

\section{Pemeriksaan IgG Chlamydia trachomatis}

Prevalensi infeksi Chlamydia trachomatis berdasar pemeriksaan imunoglobulin $\mathrm{G}$ pada wanita infertil yang menjalani laparoskopi didapatkan 16 dari 42 subyek $(38,10 \%)$. Penelitian di USA didapatkan prevalensi imunoglobulin G Chlamydia trachomatis pada $28,9 \%$ wanita infertil yang akan menjalani fertilisasi in vitro. Prevalensi lebih besar didapatkan pada wanita infertil yang dilakukan penelitian di Nigeria dengan prevalensi sebesar $74 \%$, sedangkan di India sebesar 55\%. ${ }^{19,20}$

Penelitian ini memiliki kelemahan mengenai bias dalam pemilihan subyek penelitian. Hanya wanita infertilitas yang telah ditentukan untuk dilakukan tindakan laparoskopi yang masuk dalam subyek penelitian, dan bukan wanita infertil secara keseluruhan. Hal ini dimaksudkan untuk mendapatkan data megenai kondisi tuba fallopi pada subyek, dimana laparoskopi merupakan pemeriksaan baku emas untuk melakukan evaluasi tuba fallopi. Karenanya bias ini sulit untuk dihindari mengingat laparoskopi juga merupakan prosedur yang tidak rutin dikerjakan dengan pertimbangan sifatnya yang invasif dan memerlukan biaya yang besar. Bias ini juga dibahas pada penelitian lain yang serupa dan menjadi salah satu kekurangan yang disadari. ${ }^{21}$

Bila dilihat secara kualitatif, kadar antibodi terhadap IgG Chlamydia trachomatis yang diperiksa dengan metode ELISA tampak berbeda antara kelompok dengan tuba fallopi yang mengalami kerusakan dan yang normal (gambar 1). Berdasarkan uji MannWhitney U didapatkan hasil bahwa distribusi kadar antibodi IgG Chlamydia trachomatis berbeda signifikan antara kelompok tuba fallopi rusak dan normal dengan nilai $\mathrm{p}=0.03$.

\section{Kondisi tuba fallopi berdasar temuan laparoskopi}

Kerusakan tuba fallopi menyebabkan 30-35\% infertilitas pada wanita. Kerusakan tuba fallopi disebabkan karena penyakit radang panggul, endo-metriosis, dan riwayat operasi sebelumnya. ${ }^{22,23}$ Pada penelitian ini infeksi Chlamydia trachomatisdi masa lampau merupakan faktor yang berbeda secara signifikan pada subyek dengan kerusakan tuba fallopi yang dideteksi melalui IgG Chlamydia trachomatis $(\mathrm{p}=0,01)$, sedangkan endometriosis dan riwayat operasi pada penelitian ini didapat hasil yang tidak signifikan $(\mathrm{p}=$ 0,26 dan $\mathrm{p}=0,27$ ) seperti tercantum dalam tabel 2 . Hal ini dapat menjadi indikasi bahwa infeksi Chlamydia trachomatis sebagai penyebab kerusakan akibat proses inflamasi pada tuba fallopi dan penanda infeksi ini sebagai prediktor terhadap kondisi tuba fallopi. Subyek dengan IgG Chlamydia trachomatis memiliki risiko 5,5 kali untuk didapatkan kerusakan tuba fallopi dibanding subyek tanpa $\mathrm{IgG}$ (OR 5.5 dengan $\mathrm{CI}=95 \%, 1.42-21$. 7). Hasil awal ini dapat memberikan gambaran bagaimana infeksi Chlamydia trachomatis sebagai faktor risiko pada wanita infertil di rumah sakit ini, walaupun belum bisa disimpulkan untuk populasi infertilitas seluruhnya. Sebuah meta-analisa menyimpulkan bahwa 
pemeriksaan serologi untuk mendeteksi antibodi terhadap Chlamydia trachomatis menggunakan metode ELISA atau MIF dapat digunakan sebagai alat untuk mendeteksi adanya kerusakan tuba fallopi. ${ }^{24}$

Dari hasil penelitian ini, pemeriksaan IgG Chlamydia trachomatis memiliki sensisitifitas $62,5 \%$ dan spesifisitas $81,25 \%$ dalam mendeteksi kerusakan tuba fallopi dengan menggunakan laparoskopi sebagai pemeriksaan standar dalam mengevaluasi kondisi tuba fallopi. Nilai PPV pemeriksaan ini adalah $62,5 \%$ dan NPV $81,25 \%$. Kerusakan tuba fallopi yang dimaksudkan disini adalah adanya satu atau lebih dari kondisi perlekatan perituba, oklusi tuba, fimosis fimbria atau hidrosalping. Dari hasil ini, pemeriksan serologi dapat menjadi pilihan selain HSG dalam pemeriksaan wanita infertil. Pemeriksaan ini dapat berperan sebagai alat penapis untuk memutuskan wanita infertil mana yang seharusnya dilakukan pemeriksaan laparoskopi lebih dini.

Dalam penelitian ini Chlamydia trachomatis yang terdeteksi melalui pemeriksaan isolat dengan PCR seluruhnya didapatkan imunoglobulin G juga (100\%) sehingga kami belum bisa menganalisa peranan isolat Chlamydia trachomatis pada kondisi tuba fallopi. Diperlukan penelitian lebih lanjut untuk mempelajari mengenai hal tersebut. Akan tetapi hasil ini menjadi menarik karena mengarah pada fenomena terjadinya infeksi berulang pada subyek penelitian tersebut.

\section{SIMPULAN}

Kejadian infeksi Chlamydia trachomatispada wanita infertil cukup tinggi, sebesar $14,29 \%$ berdasar PCR usapan endoserviks dan $38,10 \%$ berdasar IgG serum. Infeksi Chlamydia trachomatis memiliki peranan sebagai faktor risiko terjadinya kerusakan pada tuba fallopi. Penanda adanya infeksi berupa pemeriksaan imunoglobulin G Chlamydia trachomatis dapat membantu memberikan gambaran mengenai kondisi tuba fallopi pada wanita dengan infertilitas.

\section{DAFTAR PUSTAKA}

1. Akande VA. Tubal pelvic damage: prediction and prognosis. Hum Fertil. 2002;5(1):15-20.

2. Patton DL, Sweeney YC, Kuo C. Demonstration of Delayed Hypersensitivity in Chlamydia trachomatis Salpingitis in Monkeys: A Pathogenic Mechanism of Tubal Damage. J Infect Dis. 1994;169:680-3.

3. Brunham RC, Rey-Ladino. Immunology of Chlamydia infection: implications for a Chlamydia trachomatis vaccine. Nature reviews immunology. 2005;5:140-61.
4. Wilson JS, Honey E, Templeton A, Paavonen J, Mardh PA, Stary A, et al. A systematic review of the prevalence of Chlamydia trachomatis among European women. Hum Reprod Update. 2002;28: 385-94.

5. Rashidi BH, Chamani-Tabriz L, Haghollahi F, Jeddi-Tehrani M, Naghizadeh MM, Shariat M, et al. Effects of Chlamydia trachomatis Infection on Fertility; A Case-Control Study. J Reprod Infertil. 2013;14(2):67-72.

6. Jeremiah I, Okike O, Akani C. The prevalence of serum immunoglobulin $\mathrm{G}$ antibody to Chlamydia trachomatis in subfertile women presenting at the University of Port Harcourt teaching hospital, Nigeria. Int J Biomed Sci. 2011;7(2):120-4.

7. Tanudyaya FK, Rahardjo E, Bollen LJM, Madjid N, Daili SF, et al. Prevalence of sexually transmitted infections and sexual risk behavior among female sex workers in nine provinces in Indonesia. Southeast Asian J Trop Med Public Health. 2010;41(2):463-73.

8. Lumintang H, Murtiastutik D, Saptandari P, Merthaniasih NM, Samsulhadi. Study on chlamydial lower genital tract infection among female adolescents in Surabaya. 2004.

9. Hinting A, Soehartono, Barakbah J, Ernawan Y, Lunardhi $\mathrm{H}$, Winarso $\mathrm{H}$, et al. Prevalence of chlamydial urethral infection in male university students in Surabaya. 2005.

10. Sari DW. Insidensi Chlamydia trachomatis pada servisitis dengan keluhan dan tanpa keluhan berdasar pemeriksaan Reaksi Rantai Polimerasi (RRP). 2008.

11. Hiroi $H$, Fujiwara $T$, Nakazawa $M$, Osuga $Y$, Momoeda $\mathrm{M}$, et al. High incidence of tubal dysfunction is determined by laparoscopy in cases with positive Chlamydia trachomatis antibody despite negative finding in prior hysterosalpingography. Reproductive Medicine and Biology. 2007;6:39-43.

12. Rashidi BH, Chamani-Tabriz L, Haghollahi F, Jeddi-Tehrani M, Naghizadeh MM, Shariat M, et al. Effects of Chlamydia trachomatis Infection on Fertility; A Case-Control Study. J Reprod Infertil. 2013;14(2):67-72.

13. Dhawan B, Rawre J, Ghosh A, Malhotra N, Ahmed MM, Sreenivas V, Chaudhry R. Diagnostic efficacy of a real time-PCR assay for Chlamydia trachomatis infection in infertile women in north India. Indian J Med Res. 2014;140:252-61.

14. Dielissen PW, Teunissen DM, Lagro-Janssen TM. Chlamydia prevalence in the general population: is there a sex difference? A systematic review. BMC Infectious Diseases. 2013;13:534.

15. Westrom L, Joesoef R, Reynolds G, Hadgu A, Thompson SE. Pelvic inflammatory disease and 
fertility: a cohort study of 1,844 women with laparoscopically verified disease and 657 control women with normal laparoscopy results. Sex Transm Dis. 1992;19:185-92.

16. Neuer A, Spandorfer SD, Giralso P, et al. The role of heat shock proteins in reproduction. Hum Reprod Update. 2000;6:149-59.

17. Witkin SS, Sultan KM, Neal JJ, et al. Unsuspected Chlamydia trachomatis infection and in vitro fertilization outcome. Am. J. Obstet. Gynecol. 1994;171:1208.

18. Camus E, Poncelet C, Goffinet F, Wainer B, Merlet F, Nisand I and Philippe HJ. Pregnancy rates after in-vitro fertilization in cases of tubal infertility with and without hydrosalpinx: a meta-analysis of published comparative studies. Human Reproduction. 1999;14(5):1243-9.

19. Jeremiah I, Okike O, Akani C. The Prevalence of Serum Immunoglobulin G Antibody to Chlamydia trachomatis in Subfertile Women Presenting at the
University of Port Harcourt Teaching Hospital, Nigeria. Int J Biomed Sci. 2011;7 (2):120-4.

20. Malik A, Jain S, Hakim S, Shukla I and Rizvi M. Chlamydia trachomatis infection \& female infertility. Indian J Med Rea. 2006;123:770-5.

21. Hartog JE, Land JA, Stassen FRM, Kessels AGH, Bruggeman CA. Serological markers of persistent C. trachomatis infections in women with tubal factor subfertility. Hum Reprod. 2005;20(4):98690.

22. Kodaman PH, Arici A, Seli E. Evidence-based diagnosis and management of tubal factor infertility. Curr Opin Obst Gynecol. 2004;16:221-9.

23. Halis G, Arici A. Endometriosis and Inflammation in Infertility. Ann N Y Acad Sci. 2004;1034:30015.

24. Mol BW, Dijkman B, Wertheim P, Lijmer J, van der Veen F and Bossuyt PM. The accuracy of serum chlamydial antibodies in the diagnosis of tubal pathology: a meta-analysis. Fertil Steril. 1997;67:1031-7. 